somewhat in structure to that of brasiliensis. It differs from that species however in size and in being of a more rounded oval shape.

$H a b$. Brazil? I am indebted for this species to Mr. Dallas, who found it in a collection of insects chiefly from Brazil. Mus. Brit.

February 24, 1852.

W. J. Broderip, Esq., F.R.S., V.P., in the Chair.

The following papers were read :-

1. Description of a new species of Helix from Van Diemen's Land. By Lovelt Reeve, F.L.S. etc.

(Mollusca, Pl. XIII.)

Helix Launcestonensis. Hel. testa umbilicatâ, abbreviatoconoideâ, trochiformi, supernè rugosa et ferrugineă, quasi epi-

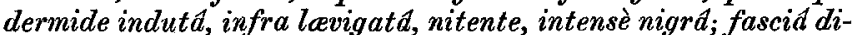
stinctâ luted cingulatá; spirâ obtusâ; anfractibus sex, supernè convexis, medio concavis, carinis lineisque gemmulatis undique cingulatis, peripherid acutè carinată, basi convexâ; umbilico mediocri, pervio, subprofundo; aperturá oblique lunari, peristomate tenui, vix reflexo, margine columellari breviter dilatato.

Hab. Launceston, Van Diemen's Land.

This very characteristic new species of Helix has just been received from Van Diemen's Land, where it was collected last summer by Mr. Ronald Gunn in a dense beech forest, north-east of Launceston. It differs materially from any of vast numbers of Helices now known to conchologists, especially in the different character of the upper and lower parts of the shell. The upper portion of the whorls has a rough rusty surface encircled by numerous finely beaded lines and keels; the lower surface is smonth and shining, jet-black, encircled by a distinct yellow band.

2. On the Habits of Strigops habroptilus or Kakapo. By David Lyall, M.D., R.N., Late Surgeon to H.M.S. Acheron.

(Aves, Pl. XLVI.)

Although the Kakapo is said to be still found occasionally on some parts of the high mountains in the interior of the north island of New Zealand, the only place where we met with it, during our circumnarigation and exploration of the coasts of the islands in H.M.S. Acheron, was at the S.W. end of the middle island. There, in the deep sounds which intersect that part of the island, it is still found in considerable numbers, inhabiting the dry spurs of hills or flats near the banks of rivers, where the trees are high, and the forest comparatively free from fern or underwood. 
The first place where it was obtained was on a hill nearly 4000 feet above the level of the sea. It was also found living in communities on flats near the mouths of rivers close to the sea. In these places its tracks were to be seen resembling footpaths made by man, and leading us at first to imagine that there must be natives in the neighbourhood. The tracks are about a foot wide, regularly pressed down to the edges, which are two or three inches deep amongst the moss, and cross each other usually at right-angles.

The Kakapo lives in holes under the roots of trees, and is also occasionally found under shelving rocks. The roots of many New Zealand trees growing partly above ground, holes are common under them; but where the Kakapo is found many of the holes appeared to have been enlarged, although no earth was ever found thrown out near them. There were frequently two openings to these holes, and occasionally, though rarely, the trees over them were hollow for some distance up.

The only occasion on which the Kakapo was seen to fly was when it got up one of these hollow trees and was driven to an exit higher up. The flight was very short, the wings being scarcely moved; and the bird alighted on a tree at a lower level than the place from whence it had come, but soon got higher up by climbing, using its tail to assist it.

Except when driven from its holes, the Kakapo is nerer seen during the day, and it was only by the assistance of dogs that we were enabled to find it.

Before dogs became common, and when the bird was plentiful in inhabited parts of the islands, the natives were in the habit of catching it at night, using torches to confuse it. It offers a formidable resistance to a dog, and sometimes inflicts severe wounds with its powerful claws and beak. At a very recent period it was common all over the west coast of the Middle Island, but there is now a race of wild dogs said to have overrun all the northern part of this shore, and to have almost extirpated the Kakapos wherever they have reached. Their range is said to be at present confined by a river or some such physical obstruction, and it is to be feared that if they once succeed in gaining the stronghold of the $K$ akapo (the S.W. end of the island) the bird may soon become extinct.

During the latter half of February and the first half of March, whilst we were annongst the haunts of these birds, we found young ones in many of the holes, frequently only one, never more than two, in the same hole. In one case where there were two young ones I found also an addled egg. There was usually, but not always, an old bird in the same hole with the young ones.

They build no nest, but simply scrape a slight hollow amongst the dry dust formed of decayed wood. The young were of different ages, some being nearly fully fledged, and others covered only with down. The egg is white and about the size of a pigeon's. (Aves, Pl. XLVI.)

The cry of the Kakapo is a hoarse croak, varied occasionally by a discordant shriek when irritated or hungry. The Maories say that during winter they assemble together in large numbers in caves, and 
at the times of meeting, and, again before dispersing to their summer haunts, that the noise they make is perfectly deafening.

A good many young ones were brought on board the ship alive. Most of them died a few days afterwards, probably from want of sufficient care; some died after being kept a month or two, and the legs of others became deformed after they had been a few weeks in captivity. The cause of the deformity was supposed to be the want of proper food, and too close confinement. They were fed chiefly on soaked bread, oatmeal and water, and boiled potatoes. When let loose in a garden they would eat lettuces, cabbages and grass, and would taste almost every green leaf that they came across. One, which I brought within six hundred miles of England (when it was accidentally killed), whilst at Sydney, ate eagerly of the leaves of a Banksia and several species of Eucalyptus, as well as grass, appearing to prefer them all to its usual diet of bread and water. It was also very fond of nuts and almonds, and during the latter part of the homeward voyage lived almost entirely on Brazilian ground-nuts.

On several occasions the bird took sullen fits, during which it would eat nothing for two or three days at a time, screaming and defending itself with its beak when any one attempted to touch it. It was at all times of an uncertain temper, sometimes biting severely when such a thing was least expected. It appeared to be always in the best bumour when first taken out of its box in the morning, hooking on eagerly with its upper mandible to the finger held down to lift it out. As soon as it was placed on the deck it would attack the first object which attracted its attention-sometimes the leg of my trowsers, sometimes a slipper or a boot. Of the latter it was particularly fond: it would nestle down upon it, flapping its wings and showing every symptom of pleasure. It would then get up, rub against it with its sides, and roll upon it on its back, striking out with its feet whilst in this position.

One of these birds, sent on shore by Capt. Stokes to the care of Major Murray of the 65th Regiment at Wellington, was allowed to run about his garden, where it was fond of the society of the children, following them like a dog wherever they went.

Nearly all the adult Kakapos which I skinned were exceedingly fat, having a thick layer of oily fat or blubber on the breast which it was very difficult to separate from the skin. Their stomachs contained a pale green, sometimes almost white, homogeneous mass, without any trace of fibre in it.

There can be little doubt but that their food consists partly of roots (their beaks are usually more or less covered with indurated mud), and partly of the leaves and tender shoots of various plants. At one place where the birds were numerous we observed that the young shoots of a leguminous shrub growing by the banks of a river were all nipped off, and this was said by our pilot, who had frequented these places for many years in a whaling vessel, to be the work of the Kakapo.

Their flesh is white, and is generally esteemed good eating. No. CCXL.-Procendings or The Zoological Society. 


\section{On two new species of South American Birds.} By Phimip Luthey Sclater.

(Aves, Pl. XLVII. XLVIII.)

1. Culicivora boliviana, Sclater. C. suprà plumbea; infrà alba plumbeo paululìm tincta; ventre niveo; fronte regione oculari et genis nigris; alis nigricantibus, tectricibus et secundariis latè, primariis strictissimè albo limbatis ; cauda nigra lateralibus rectricibus albo terminatis 4 ; extimis ferè omnind albis-rostro et pedibus nigris.

Long. tota $4 \frac{3}{4}$; alæ $2 \frac{1}{8}$; caudæ $2 \frac{1}{4}$.

$H a b$. Bolivia (Bridges), D'Orbigny.

The present bird is the fifth of this interesting genus, of which the best known are the C. crerulea (Linn.) of the United States, and the C.dumicola (Vieill.) of Brazil and Paraguay. The Prince of Canino notices two other previously unrecognized species in his ' Conspectus Avium,' p. 316. These I have never seen; but his fifth species, the C. budytoides, De la Fresnaye, of which I have examined the type, belongs, I believe, more properly to another genus. There are specimens of the present species in the British and Paris $\mathrm{Mu}$ seums, and in the fine collection of the Baron de la Fresnaye at La Fresnaye near Falaise.

2. Pipra flavo-tincta, Sclater. P. alba, favo pallide tincta; pileo alis caudâque cum dorso inferiore nigris; uropygio cum ventre viridescente-cinereis; rostro nigro; pedibus flavis.

Long. tota $3 \frac{1}{2}$; alæ $1 \frac{7}{8}$; caudæ $1 \frac{1}{8}$.

$H a b$. S $^{\text {ta }}$ Fe de Bogota.

This species is very like the common Pipra manacus, but is smaller, and has the white parts of its plumage tinged with yellow and much less black on the back. There are examples in the Museum of the Jardin des Plantes at Paris and of the Baron de la Fresnaye.

March 9, 1852.

John Gould, Esq., F.R.S., in the Chair.

The following papers were read :-

1. Descriptions of new species of Cleride, from Asia, Africa ANd Australia.

By J. O. Westwood, F.L.S., Pres. Ent. Soc. etc.

\section{(Annulosa, Pl. XXIV. XXV. XXVI. XXVII.)}

The fine illustrated memoirs on the family Clerida lately published by Dr. Klug and the Marquis Spinola, and the Catalogue of the same family still more recently issued by the British Museum, from the 